\title{
Effects of Modification and Co-Aging with Soils on Cd(II) Adsorption Behaviors and Quantitative Mechanisms by Biochar
}

\section{Zhuowen Meng}

Wuhan University

Shuang Huang ( $\sim$ hsh5527@whu.edu.cn )

Wuhan University https://orcid.org/0000-0002-0071-6055

Zhongbing Lin

Wuhan University

\section{Research Article}

Keywords: Biochar, Modification, Cadmium, Adsorption, Mechanisms, Co-aging.

Posted Date: December 14th, 2021

DOI: https://doi.org/10.21203/rs.3.rs-1083831/v1

License: (c) (i) This work is licensed under a Creative Commons Attribution 4.0 International License.

Read Full License

Version of Record: A version of this preprint was published at Environmental Science and Pollution Research on January 18th, 2022. See the published version at https://doi.org/10.1007/s11356-02218637-w. 


\section{Abstract}

In this study, original rice straw biochar and two $\mathrm{KMnO}_{4}$-modified biochars (pre- and postmodification) were prepared, which were all pyrolysed at $400^{\circ} \mathrm{C}$. Premodified biochar had the largest Cd adsorption capacity, strongest acid and solute buffering capacity, which benefited from the increase of carbonate content, specific surface area and the emergence of $\mathrm{Mn}(\mathrm{II})$ and $\mathrm{MnO}_{\mathrm{x}}$ through modification. Original and premodified biochars were then conducted four types of aging process, namely, aging without soil, coaging with acid $(\mathrm{pH}=5.00)$, neutral $(\mathrm{pH}=7.00)$ and alkaline $(\mathrm{pH}=8.30)$ soils, using an improved three-layer mesh method. The adsorption capacities of modified biochar were always larger than those of original biochar after aging processes. After four aging processes, $\mathrm{Cd}$ (II) adsorption capacities were basically in the order of aged biochar without soil > biochar co-aged with alkaline soil > biochar co-aged with neutral soil > biochar co-aged with acid soil, and $\mathrm{KMnO}_{4}$-modified biochar was always better than original biochar after co-aging with soils. The dominant adsorption mechanism of original and premodified biochars (fresh and aged) for $\mathrm{Cd}$ (II) was all the precipitation and adsorption with minerals (accounted for $58.55 \% \sim 85.55 \%)$. In this study, we highlighted that biochar remediation for $\mathrm{Cd}$ should be evaluated by coaging with soil instead of aging without soil participation.

\section{Introduction}

In recent years, farmland soils have been seriously polluted by heavy metals from exhaust gas emissions, mining and smelting, of which cadmium (Cd) is recognized as one of the most dangerous heavy metals due to its high toxicity and fluidity; more seriously, it can be enriched in fruits, vegetables, aquatic organisms and eventually enter the human body through food chain, causing kidney failure and other diseases (Chen et al., 2008; Li et al., 2010; Liu et al., 2010; Rizwan et al., 2016). Currently, in situ technology is considered as one of the most cost-effective remediation methods to deal with heavy metal pollution (Inyang et al., 2012; Sun et al., 2013). As an in situ remediation agent, the high efficiency of biochar on Cd remediation in the soil has been verified due to its unique physicochemical properties, including high pH value, large cation amounts and huge specific surface area, etc. (Ahmad et al., 2018; Cai et al., 2021; Fan et al., 2020; Trakal et al., 2014; Meng et al., 2013; Qian et al., 2016).

Many studies indicated that $\mathrm{Cd}(\mathrm{II})$ adsorption capacities of biochars prepared in laboratory muffle furnace basically increased with increasing pyrolysis temperatures from 300 to $700^{\circ} \mathrm{C}$ (Deng et al., 2018; Deng et al., 2019). However, it is difficult to produce biochar pyrolyzed at relatively high temperatures (i.e. $500 \sim 700^{\circ} \mathrm{C}$ ) under large-scale factory conditions, but $\mathrm{Cd}(\mathrm{II})$ adsorption capacities of original biochars pyrolyzed at relatively low temperatures were limited (Han et al., 2013b; Liu \& Fan, 2018). Therefore, to realize the large-scale application of biochar in the field, researches of modified biochars pyrolyzed at relatively low temperature (i.e. $300 \sim 400^{\circ} \mathrm{C}$ ) should be increasingly carried out (Wang et al., 2017). Currently, modification methods are mainly divided into physical modification (Lyu et al., 2018; Rajapaksha et al., 2015) and chemical modification (Hadjittofi et al., 2014; Song et al., 2014). As a relatively inexpensive reagent, $\mathrm{KMnO}_{4}$ has been increasingly applied to modify biochars in recent years, 
and the maximum $\mathrm{Cd}(\mathrm{II})$ adsorption capacities of $\mathrm{KMnO}_{4}$-modified biochars were $2.16 \sim 5.9$ times original ones (Li et al., 2017; Liang et al., 2017; Wang et al., 2015a; Yin et al., 2019).

Although stable properties have been frequently reported for biochars, once applied in soil, biochar will interact with soil and inevitably experience a series of aging processes in the field. Aging in soils can cause property changes of biochar, and further affect $\mathrm{Cd}$ (II) adsorption behaviors of biochar (Wang et al., 2020). The modification effects of $\mathrm{KMnO}_{4}$ can not be judged only by $\mathrm{Cd}(\mathrm{II})$ adsorption capacity of fresh biochar, but also the property changes and $\mathrm{Cd}(\mathrm{II})$ adsorption behaviors of modified biochar after co-aging with soil. Moreover, $\mathrm{Cd}(\mathrm{II})$ adsorption behaviors of biochars after co-aging with soil might vary in soils with different $\mathrm{pH}$. Therefore, it is necessary to investigate the effects of co-aging with different soils on $\mathrm{Cd}(\mathrm{II})$ adsorption behaviors by biochars. Due to the long time cost of natural aging, artificial accelerated aging methods have been increasingly employed to simulate long-term aging process in the field (Chang et al. 2019; Fan et al., 2018; Quan et al. 2020). However, most previous studies investigated aging effects on biochar adsorption behaviors only based on aged biochars without soil participation, which was far from natural aging of biochar in field soils (Deng et al., 2020), because it is a big challenge to separate biochar from soil. Therefore, it is necessary to investigate biochar remediation effects for $\mathrm{Cd}$ by co-aging with soil.

$\mathrm{Cd}(\mathrm{II})$ adsorption mechanisms is important to reveal the modification effects of biochar. Currently, the adsorption mechanisms between biochar and heavy metal ions mainly include cation exchange, complexation, precipitation and other potential mechanisms (Cui et al., 2016; Wang et al., 2015b). Deng et al. (2019) indicated that cation exchange and precipitation with minerals were respectively the main $\mathrm{Cd}(\mathrm{II})$ adsorption mechanisms of rice straw biochars pyrolyzed at 400 and $700{ }^{\circ} \mathrm{C}$. However, it is still unclear the effects of modification and co-aging with soils on $\mathrm{Cd}(\mathrm{II})$ adsorption mechanisms by biochar.

In this study, an improved three-layer mesh method was conducted to ensure the close contact between soil and biochar during aging, meanwhile realizing the easy separation of biochars after aging. Thereby biochars after co-aging with acid, neutral and alkaline soils were obtained, then the acid and solute buffering capacity, $\mathrm{Cd}(\mathrm{II})$ adsorption behaviors and mechanisms of co-aged biochars were investigated. Here we test the hypothesis that both modification and co-aging with soils affect $\mathrm{Cd}$ (II) adsorption behaviors and mechanisms of biochar. The main objects of this study were 1) to compare the adsorption capacities, acid and solute buffering capacity of original and modified biochars; 2 ) to investigate effects of aging without soil participation and co-aging with soil on $\mathrm{Cd}(\mathrm{II})$ adsorption behaviors and mechanisms by original and modified biochars.

\section{Materials And Methods}

\subsection{Preparation of original and modified biochars}

Original biochar (BC) was prepared as a control, in brief, rice straw biomass $(<0.3 \mathrm{~mm})$ was filled into a crucible sealed with tin foil, which was then placed in a muffle furnace, heated to $400^{\circ} \mathrm{C}$ and held for 4 
hours before cooling to room temperature.

Premodified and postmodified biochars were prepared using $0.1 \mathrm{~mol} \cdot \mathrm{L}^{-1} \mathrm{KMnO}_{4}$ solution (Wang et al., 2015a). For premodified biochar (MBC), briefly, $50 \mathrm{~g}$ of rice straw biomass was immersed in $250 \mathrm{~mL}$ of $0.1 \mathrm{~mol} \cdot \mathrm{L}^{-1} \mathrm{KMnO}_{4}$ solution and sonicated for two hours to make them react adequately, and the mixture was then dried in an oven, ground and sieved to $<0.3 \mathrm{~mm}$, and the subsequent pyrolyzing process was the same as $\mathrm{BC}$. Postmodified biochar (OBC) was prepared by reacting $\mathrm{BC}$ with $0.1 \mathrm{~mol} \cdot \mathrm{L}^{-1} \mathrm{KMnO}_{4}$ solution using the same method described above and then dried in an oven, ground and sieved to $<0.3 \mathrm{~mm}$.

\subsection{Biochar characterization}

Carbonate contents of biochars were measured according to the hydrochloric acid titration method, and the elemental analyzer (RARIO EL III, Elementar, Germany) was employed to analyze the contents of carbon, hydrogen and nitrogen in biochars. The surface areas of biochars were detected using the BET method and porosity analyzer (ASAP 2020M, Mike, USA). Field Emission Scanning Electron Microscope (FESEM, Zeiss SIGMA, Carl Zeiss, England) was applied to detect the changes in the element contents and surface morphology of biochars. The surface functional groups were determined by using Fourier Transform Infrared Spectrometer (FTIR5700, Thermo, USA) by measuring the absorbance from 400 to $4000 \mathrm{~cm}^{-1}$. X-Ray Diffractomer (XRD, XPert Pro, Panaco, Holland) was used to study the crystalline minerals on biochars, especially the crystalline Mn minerals. X-ray Photoelectron Spectroscopy (XPS, Thermo, USA) was carried out to determine the existing forms of $\mathrm{MnO}_{\mathrm{X}}$ on two modified biochars. The basic properties of three biochars are listed in Table 1, and the images of XPS, FTIR, XRD and FESEMEDS are respectively shown in Fig. 3, Fig. 4, Fig. 5 and Fig. S1. 
Table 1

The basic physicochemical properties of ten types of biochar.

\begin{tabular}{|c|c|c|c|c|c|c|c|}
\hline Property & $\stackrel{\mathrm{pH}}{\left(\mathrm{CaCl}_{2}\right)}$ & $\begin{array}{l}\mathrm{C} \\
(\%)\end{array}$ & $\begin{array}{l}\mathrm{H} \\
(\%)\end{array}$ & $\begin{array}{l}N \\
(\%)\end{array}$ & $\begin{array}{l}\text { BET-SA } \\
\left(m^{2} \cdot g^{-1}\right)\end{array}$ & $\begin{array}{l}\text { Yield } \\
(\%)\end{array}$ & $\begin{array}{l}\text { Carbonate content } \\
\text { (\%) }\end{array}$ \\
\hline $\mathrm{BC}$ & $9.70 \pm 0.02$ & 49.8 & 3.1 & 0.8 & 3.6 & 37 & 1.6 \\
\hline MBC & $9.60 \pm 0.1$ & 38.3 & 3.2 & 0.8 & 19.4 & 52.4 & 5.7 \\
\hline OBC & $8.80 \pm 0.05$ & 42.8 & 3.2 & 0.9 & 3.9 & 37 & 1.3 \\
\hline PBC & $8.05 \pm 0.03$ & 51.7 & 3.5 & 0.8 & 6.43 & & \\
\hline PMBC & $7.92 \pm 0.01$ & 46.7 & 3.9 & 0.8 & 4.42 & & \\
\hline$A B C$ & $5.05 \pm 0.02$ & 48.6 & 3.6 & 0.9 & 10.91 & & \\
\hline AMBC & $6.00 \pm 0.03$ & 41.7 & 3.7 & 0.9 & 7.44 & & \\
\hline BBC & $5.90 \pm 0.02$ & 52.3 & 3.6 & 0.9 & 9.96 & & \\
\hline BMBC & $6.10 \pm 0.05$ & 45.4 & 3.9 & 0.9 & 9.01 & & \\
\hline СВС & $7.38 \pm 0.03$ & 52.8 & 3.8 & 0.9 & 7.21 & & \\
\hline CMBC & $7.56 \pm 0.01$ & 43.1 & 4 & 0.8 & 9.77 & & \\
\hline \multicolumn{8}{|l|}{ Notes: } \\
\hline \multicolumn{8}{|c|}{$\mathrm{BC}$ is original biochar, } \\
\hline \multicolumn{8}{|c|}{$\mathrm{MBC}$ is $\mathrm{KMnO}_{4}$-premodified biochar, } \\
\hline \multicolumn{8}{|c|}{$\mathrm{OBC}$ is $\mathrm{KMnO}_{4}$-postmodified biochar, } \\
\hline \multicolumn{8}{|c|}{ PBC is aged original biochar without soil; } \\
\hline \multicolumn{8}{|c|}{ PMBC is aged $\mathrm{KMnO}_{4}$-premodified biochar without soil; } \\
\hline \multicolumn{8}{|c|}{ ABC is original biochar co-aged with acid soil; } \\
\hline \multicolumn{8}{|c|}{ AMBC is $\mathrm{KMnO}_{4}$-premodified biochar co-aged with acid soil; } \\
\hline \multicolumn{8}{|c|}{ BBC is original biochar co-aged with neutral soil; } \\
\hline \multicolumn{8}{|c|}{$\mathrm{BMBC}$ is $\mathrm{KMnO}_{4}$-premodified biochar co-aged with neutral soil; } \\
\hline \multicolumn{8}{|c|}{ CBC is original biochar co-aged with alkaline soil; } \\
\hline
\end{tabular}

\subsection{Adsorption isotherms and adaptability of original and modified biochars}


To determine $\mathrm{Cd}(\mathrm{II})$ adsorption isotherms of biochars, $0.02 \mathrm{~g}$ of biochar sample was added to a centrifuge tube containing $20 \mathrm{~mL}$ of $\mathrm{Cd}(\mathrm{II})$ solution ( $\mathrm{pH}=5.5$ ) with a background electrolyte of $0.01 \mathrm{~mol} \cdot \mathrm{L}^{-1} \mathrm{NaNO}_{3}$ solution, and the $\mathrm{Cd}$ (II) concentrations ranged from 5 to $200 \mathrm{mg} \cdot \mathrm{L}^{-1}$. After centrifuge tubes were shaken in a water bath shaker at $200 \mathrm{rpm}$ for 24 hours at $25^{\circ} \mathrm{C}$, the sample was then withdrawn, and subsequently filtered through $0.45 \mu \mathrm{m}$ nylon membrane filters. The $\mathrm{Cd}(\mathrm{II})$ concentration in the filtrate was detected by flame atomic absorption spectrometry (AAS, Agilent 240 Duo AA, USA).

To evaluate the adaptability of modified biochars, the adsorption capacities of biochars under different $\mathrm{pH}$ and ionic strength conditions were also tested. Biochars were added to $\mathrm{Cd}(\mathrm{II})$ solutions $\left(200 \mathrm{mg} \cdot \mathrm{L}^{-1}\right)$ with different $\mathrm{pH}$ values (3.0-7.0) and ionic strength (0-0.1 $\left.\mathrm{mol} \cdot \mathrm{L}^{-1} \mathrm{Na}(\mathrm{I})\right)$. After the 24 hours of shaking at $200 \mathrm{rpm}$ in a water bath shaker at room temperature, the same procedures were conducted as described above to determine $\mathrm{Cd}(\mathrm{II})$ concentrations. To further study the adaptability of modified biochars under acidic contaminated conditions, an acid buffer experiment was carried out. In brief, $1 \mathrm{~g}$ of biochar was added to $20 \mathrm{~mL}$ of $0.01 \mathrm{~mol} \cdot \mathrm{L}^{-1} \mathrm{CaCl}_{2}$ solution, and $0.5 \mathrm{~mL}$ of $2 \% \mathrm{HNO}_{3}$ solution was added each time, then the sample was shaken at $200 \mathrm{rpm}$ for 12 hours, and the $\mathrm{pH}$ value was measured, of which this operation was repeated for 8 times.

\subsection{Preparation of co-aged biochars}

According to the results of $\mathrm{Cd}(\mathrm{II})$ adsorption capacities and adaptability of biochars in aqueous solutions, MBC was obviously better than OBC; therefore, only MBC was selected to co-age with soils in the following experiments, and $\mathrm{BC}$ was used as comparison. Three kinds of non-cadmium contaminated soil, acid $(\mathrm{pH}=5.00)$, neutral $(\mathrm{pH}=7.00)$ and alkaline $(\mathrm{pH}=8.30)$, were employed in this experiment, which were respectively gathered from Nanchang City $\left(116.045^{\circ} \mathrm{E}, 28.635^{\circ} \mathrm{N}\right)$, Jingmen City $\left(112.044^{\circ} \mathrm{E}, 31.097^{\circ} \mathrm{N}\right)$ and Bayannur City $\left(107.398^{\circ} \mathrm{E}, 41.027^{\circ} \mathrm{N}\right)$, China. An improved three-layer mesh method was employed, which not only ensured close contact between soil and biochar during aging, but also realized the separation of biochars after aging (Meng et al., 2020). Briefly, four 600-mesh nylon nets $(15 \mathrm{~cm} \times 20 \mathrm{~cm}$ ) divided three inside layer spaces, which were filled with $50 \mathrm{~g}$ soil, $3 \mathrm{~g}$ fresh biochar (BC or MBC) and $50 \mathrm{~g}$ soil in order, and the outermost four sides of nylon nets were tightly sealed with glue, and finally the bottom and top of sample were fixed with stainless steel plates by clips.

Wang et al. (2020) indicated that quantitative artificial aging methods should be applied to make predictions of biochar's long-term performance. Therefore, in this experiment, freeze-thaw cycling and drywet cycling were combined to closely simulate the natural aging in the field, and the 54-day aging process simulated 6-year natural aging according to the multi-year average meteorological data of Wuhan city, China (Xu et al., 2018). Additionally, aged biochars without soil participation were also prepared for comparison.

In addition to $\mathrm{BC}$ and $\mathrm{MBC}, 8$ aged biochar were obtained after aging, namely aged biochars without soil (original: PBC; modified: PMBC), biochars co-aged with acid soil (original: ABC; modified: AMBC), biochars co-aged with neutral soil (original: BBC; modified: BMBC), and biochars co-aged with alkaline 
soil (original: $\mathrm{CBC}$; modified: $\mathrm{CMBC}$ ). The basic properties of these aged biochars are also listed in Table 1; moreover, their adsorption experiments were also conducted as the same method described in section 2.3.

\subsection{Quantitative adsorption mechanisms of biochars}

The contributions of various mechanisms to $\mathrm{Cd}$ (II) adsorption capacities of biochars were determined based on the researches of Wang et al. (2015b), Cui et al. (2016) and Deng et al. (2019), which calculated the contributions of cation exchange with $\mathrm{K}(\mathrm{I}), \mathrm{Ca}(\mathrm{II}), \mathrm{Na}(\mathrm{I})$ and $\mathrm{Mg}(\mathrm{II})\left(\mathrm{Q}_{\mathrm{ci}}\right)$, precipitation with minerals $\left(Q_{c p}\right)$, complexation with acid functional groups $\left(Q_{c f}\right)$ and other mechanisms $\left(Q_{c o}\right)$. In this study, due to the modification with $\mathrm{KMnO}_{4}$, there was a considerable amount of $\mathrm{Mn}(\mathrm{II})$ and $\mathrm{MnO}_{\mathrm{x}}$ on modified biochars; therefore, the previous mechanism division method was improved and the calculation methods are as follows:

$Q_{c}$ is the total amount of $C d(I I)$ adsorbed by biochar when $C_{e}=100 \mathrm{mg} \cdot \mathrm{L}^{-1}$, and $Q_{a}$ is the amount of $C d(I)$ adsorbed by acidified biochar, which was reacted with $1 \mathrm{M}$ hydrochloric acid solution and rinsed with ultrapure water until the $\mathrm{pH}$ of filtrate was stable, and the mineral components of biochar basically disappeared after such a treatment. Both $Q_{c}$ and $Q_{a}$ can be directly determined. $Q_{c m}$ is the adsorption amount of $\mathrm{Cd}(\mathrm{II})$ due to the interaction with minerals, which is obtained by the difference between $\mathrm{Q}_{\mathrm{C}}$ and $Q_{a}$.

$$
Q_{\mathrm{cm}}=Q_{c}-Q_{a}
$$

$\mathrm{Q}_{\mathrm{cm}}$ includes three parts, namely, $\mathrm{Q}_{\mathrm{cic}}, \mathrm{Q}_{\mathrm{Mn}}$ and $\mathrm{Q}_{\mathrm{cp}}$, where $\mathrm{Q}_{\mathrm{cic}}$ represents the amount of $\mathrm{Cd}(\mathrm{II})$ adsorption by cation exchange with $\mathrm{K}^{+}, \mathrm{Na}^{+}, \mathrm{Ca}^{2+}$ and $\mathrm{Mg}^{2+}$, and $\mathrm{Q}_{\mathrm{cp}}$ is obtained by subtracting $\mathrm{Q}_{\mathrm{cic}}$ and $\mathrm{Q}_{\mathrm{Mn}}$ from $\mathrm{Q}_{\mathrm{cm}}$.

$$
\begin{aligned}
& Q_{\text {cic }}=Q_{K}+Q_{N a}+Q_{C a}+Q_{M g} \\
& Q_{\mathrm{cp}}=Q_{c m}-Q_{c i c}-Q_{M n}
\end{aligned}
$$

where $Q_{K}, Q_{N a}, Q_{C a}, Q_{M g}$ and $Q_{M n}$ are respectively the net contents of $K(I), N a(I), C a(I I), M g(I I)$ and $M n(I I)$ released from biochar to solution after the adsorption of $\mathrm{Cd}(\mathrm{II})$.

$\mathrm{Q}_{\mathrm{a}}$ includes two parts, namely, $\mathrm{Q}_{\mathrm{cf}}$ and $\mathrm{Q}_{\mathrm{co}}$, and $\mathrm{Q}_{\mathrm{cf}}$ was calculated from the amount of $\mathrm{H}^{+}$released after the adsorption of $\mathrm{Cd}(\mathrm{II})$ on acidified biochar, i.e., the drop of $\mathrm{pH}$ value, and $\mathrm{Q}_{\mathrm{co}}$ was calculated as the difference between $Q_{a}$ and $Q_{c f}$. 


$$
Q_{\mathrm{co}}=Q_{a}-Q_{c f}
$$

\subsection{Quality assurance and quality control}

The adsorption data of $\mathrm{Cd}(\mathrm{II})$ were fitted by Langmuir (LM) and Freundlich (FM) isotherm models, and the specific equations are shown in the supplementary material. Parameters of $\mathrm{Cd}(\mathrm{II})$ adsorption on biochars obtained from Langmuir and Freundlich isotherm models are shown in Table S1. Statistical analysis was conducted on all experimental data using EXCEL 2013 software, and Origin 8.0 was used to fit the isotherm models and plotting data. All data shown in figures are the average values of three replicate experiments, and the error bars represent the standard deviation of three replicates. The relative standard deviation (RSD) of Cd determined by AAS was $2 \%$, and the detection limit was $0.002 \mathrm{mg} \cdot \mathrm{L}^{-1}$.

\section{Results And Discussion}

\subsection{Adsorption behaviors of fresh biochars (BC, $M B C$ and OBC)}

$\mathrm{Cd}(\mathrm{II})$ adsorption isotherms on $\mathrm{BC}, \mathrm{MBC}$ and $\mathrm{OBC}$ at $\mathrm{pH}=5.5$ are given in Fig. 1, the adsorption isotherms were all typical "L"-shaped isotherms and reached steady state at higher concentrations. For all fresh biochars, the fitting results of Langmuir isotherm model all had larger $R^{2}$ values $(0.996,0.969$ and 0.965 for $\mathrm{BC}, \mathrm{MBC}$ and $\mathrm{OBC}$ respectively), indicating that the chemisorption of $\mathrm{Cd}(\mathrm{II})$ mainly occurred on the homogeneous surface of BC, MBC and OBC (Cui et al., 2016; Li et al., 2017). The maximum Cd(II) adsorption capacities $\left(Q_{m}\right)$ of $B C, M B C$ and $O B C$ based on the Langmuir isotherm model were 54.26 , 117.33 and $60.52 \mathrm{mg} \cdot \mathrm{g}^{-1}$, respectively, which indicated that modification enhanced $\mathrm{Cd}(\mathrm{II})$ adsorption ability of rice straw biochar in aqueous solutions, especially the premodification.

The presence of Cd in EDS images proved that all three biochars adsorbed $\mathrm{Cd}(\mathrm{II})$, and the content of $\mathrm{Cd}$ in MBC was the largest, which was consistent with the adsorption results (Fig. S1). The SEM images showed that the surface of $\mathrm{BC}$ was complete and smooth, while that of $\mathrm{MBC}$ was relatively rough with several fine particles and crystals evenly distributed on the surface (Fig. S1), which was similar to several previous studies (Liang et al., 2017; Yin et al., 2019), and OBC was more broken compared to BC. The specific surface areas of $B C, M B C$ and $O B C$ were $3.6,19.4$ and $3.9 \mathrm{~m}^{2} \cdot \mathrm{g}^{-1}$, respectively, and the specific surface area of $M B C$ was 5.4 times that of $B C$, which might result in the significant increase in the adsorption capacity of MBC compared with BC. The maximum adsorption capacity of MBC (117.33 $\mathrm{mg} \cdot \mathrm{g}^{-1}$ ) in this study was much larger than other reported Mn-loaded biochars, indicating that rice straw is more suitable than other substrates as the raw material for $\mathrm{KMnO}_{4}$ modification (Liang et al., 2017; Fan et al., 2018; Li et al., 2017; Yin et al., 2019).

\subsection{Effects of pH and ionic strength}


Figure 2a showed that initial solution $\mathrm{pH}$ significantly affected $\mathrm{Cd}(\mathrm{II})$ adsorption by biochars. When the $\mathrm{pH}$ of $\mathrm{Cd}(\mathrm{II})$ solution was 3.0, the adsorption capacities of $\mathrm{BC}, \mathrm{MBC}$ and $\mathrm{OBC}$ were 24.47, 108.67 and $55.53 \mathrm{mg} \cdot \mathrm{g}^{-1}$, respectively, indicating that premodified biochar still had the largest $\mathrm{Cd}(\mathrm{II})$ adsorption capacity even under extremely acidic condition. When the $\mathrm{pH}$ of $\mathrm{Cd}(\mathrm{II})$ solution was 5.0 , the adsorption capacities of $B C, M B C$ and $O B C$ increased to $46.00,115.21$ and $60.26 \mathrm{mg} \cdot \mathrm{g}^{-1}$, respectively. As solution $\mathrm{pH}$ increased, the surface groups of biochars gradually deprotonated; therefore, the chance of $\mathrm{Cd}$ (II) binding to biochar structure increased, which resulted in a higher adsorption capacity (Bogusz et al., 2015). When the $\mathrm{pH}$ of $\mathrm{Cd}(\mathrm{II})$ solution further increased to 7.0, the adsorption capacities of $\mathrm{BC}, \mathrm{MBC}$ and $\mathrm{OBC}$ increased to $78.00,144.93$, and $86.53 \mathrm{mg} \cdot \mathrm{g}^{-1}$, respectively. We concluded that the adsorption capacities of MBC in $\mathrm{Cd}(\mathrm{II})$ solutions with $\mathrm{pH}$ from 3.0 to 7.0 were always significantly higher than those of $\mathrm{BC}$ and $\mathrm{OBC}$, especially under the strong acidic condition.

The changes in solution $\mathrm{pH}$ after fully reacting with biochars are shown in Fig. $2 \mathrm{~b}$. Regardless the initial $\mathrm{pH}$ of $\mathrm{Cd}(\mathrm{II})$ solution was $3.0,5.0$ or 7.0 , after reacting with $\mathrm{MBC}$, the solution $\mathrm{pH}$ was obviously higher than that treated with $\mathrm{BC}$ and $\mathrm{OBC}$, indicating that $\mathrm{MBC}$ had a stronger ability in improving the $\mathrm{pH}$ of solutions. Moreover, the acid buffer experiment (Fig. 2c) showed that modified biochars (MBC and OBC) had higher acid buffer capacities compared with original biochar. The $\mathrm{pH}$ values of $\mathrm{Cd}$ (II) solutions treated with $\mathrm{BC}, \mathrm{MBC}$ and $\mathrm{OBC}$ after the addition of $4 \mathrm{~mL}$ of $\mathrm{HNO}_{3}$ solution were $1.5,6.3$, and 4.4, respectively, which indicated that $\mathrm{MBC}$ had an extremely strong acid buffer capacity, and this was one of the most important factors resulting in its largest adsorption capacity under acidic condition. The carbonate contents of $\mathrm{BC}, \mathrm{MBC}$, and $\mathrm{OBC}$ were $1.6 \%, 5.7 \%$, and $1.3 \%$, respectively, of which $\mathrm{MBC}$ was 3.5 times that of $\mathrm{BC}$; moreover, the presence of $\mathrm{MnO}_{\mathrm{x}}$ might also enhance the acid buffer capacities of $\mathrm{MBC}$ and OBC (Fan et al., 2018).

As shown in Fig. 2d, overall, the adsorption capacities of all biochars decreased as the ionic strength increased, because metal ions and sodium ions competed for the same adsorption sites. Many previous studies also demonstrated that the amounts of target metal ions adsorbed by biochar decreased as other metal ions presented (Deng et al., 2019; Xu et al., 2013).

\subsection{Effects of modification and co-aging on biochar characterizations}

To analyze the existing forms of $\mathrm{MnO}_{\mathrm{x}}$ on $\mathrm{MBC}$ and $\mathrm{OBC}$, XPS analysis of modified biochars was carried out. As shown in Fig. $3 \mathrm{c}$ and $3 \mathrm{~d}$, the existing forms of $\mathrm{MnO}_{\mathrm{x}}$ were determined to be $\mathrm{MnO}$ on $\mathrm{MBC}$ while $\mathrm{MnO}_{2}$ on OBC by using the $\triangle \mathrm{E}$ of $\mathrm{Mn} 3 \mathrm{~s}$ (Biesinger et al., 2011). Combining with the results on Mnmodified biochars in recent years, we concluded that the form of $\mathrm{MnO}_{\mathrm{x}}$ on the biochar premodified by $\mathrm{KMnO}_{4}$ was mainly $\mathrm{MnO}$ (Fan et al., 2018; Yin et al., 2019), whereas that on postmodified biochar was mainly $\mathrm{MnO}_{2}$ (Liang et al., 2017; Xiao et al., 2019), and the effect of premodification was basically better than that of postmodification in terms of improving heavy metal adsorption of biochars. 
The $\mathrm{pH}$ values of $\mathrm{BC}$ and $\mathrm{MBC}$ were 9.70 and 9.60, indicating that premodification had almost no effect on $\mathrm{pH}$ improvement of rice straw biochar; however, the $\mathrm{pH}$ of biochars varied largely after co-aging with different types of soil. For original biochar, the order of biochar pH was $\mathrm{BC}$ (9.70) $>\mathrm{PBC}(8.05)>\mathrm{CBC}$ (7.38) > BBC (5.90) > ABC (5.05), and that of premodified biochar was $\mathrm{MBC}$ (9.60) > PMBC (7.92) > CMBC (7.56) > BMBC (6.10) > AMBC (6.00). For both original and premodified biochars, the pH values after aging without soil were obviously larger than those after co-aging with soils; moreover, for biochars coaged with soils, the $\mathrm{pH}$ values decreased with the increase of soil acidity. It could also be seen in Table 2 that after co-aging with $\mathrm{BC}$ and $\mathrm{MBC}$, the $\mathrm{pH}$ of acid, neutral and alkaline soils increased from 5.00, 7.00 and 8.30 to $6.02 / 6.61,7.06 / 7.21$ and $8.26 / 8.33$, respectively. With the increase of soil acidity, the greater the improvement effect of biochar on soil $\mathrm{pH}$, the larger the consumption of its own acid buffer capacity. After co-aging with the same soil, the $\mathrm{pH}$ of premodified biochar was always larger than that of original biochar, which showed that MBC was less affected than $B C$ during the aging process in soils, especially in acid soil. It could be found in Table 1 that the specific surface area of BC increased while that of MBC decreased after all aging treatments.

Table 2

The basic physicochemical properties of three soils.

\begin{tabular}{|c|c|c|c|}
\hline Property & Acidic soil & Neutral soil & Alkaline soil \\
\hline Initial $\mathrm{pH}\left(\mathrm{CaCl}_{2}\right)$ & $5.00 \pm 0.10$ & $7.00 \pm 0.05$ & $8.30 \pm 0.12$ \\
\hline Texture & Loamy clay & Silty loam & Sandy clay loam \\
\hline Sand (\%) & 45 & 40 & 64 \\
\hline Silt (\%) & 20 & 56 & 16 \\
\hline Clay (\%) & 35 & 4 & 20 \\
\hline Organic matter $\left(\mathrm{g} \cdot \mathrm{kg}^{-1}\right)$ & 4.42 & 10.81 & 5.32 \\
\hline CEC $\left(\mathrm{cmolc} \cdot \mathrm{kg}^{-1}\right)$ & 9.53 & 14.92 & 4.52 \\
\hline $\mathrm{pH}$ (after co-aging with $\mathrm{BC}$ ) & $6.02 \pm 0.04$ & $7.06 \pm 0.01$ & $8.26 \pm 0.12$ \\
\hline $\mathrm{pH}$ (after co-aging with $\mathrm{MBC}$ ) & $6.61 \pm 0.05$ & $7.21 \pm 0.08$ & $8.33 \pm 0.06$ \\
\hline
\end{tabular}

EDS analysis showed that $\mathrm{O}$ contents of $\mathrm{MBC}$ and $\mathrm{OBC}(27.12 \%$ and $21.48 \%)$ were higher than that of $\mathrm{BC}$ (17.36\%) (Fig. S1), which indicated that the degrees of oxidation were significantly improved after modification, and this change increased oxidative functional groups and improved the complexation effects between modified biochars and Cd(II) (Fan et al., 2018). In the FTIR spectra (Fig. 4), the broad band at approximately $3400 \mathrm{~cm}^{-1}$ corresponded to the absorption peak of hydroxyl groups (-OH) (Dutta et al., 2015), and the peaks at $1623,1382,1099$, and $784 \mathrm{~cm}^{-1}$ corresponded to $\mathrm{C}=\mathrm{O}, \mathrm{C}-\mathrm{H}_{2}, \mathrm{C}-\mathrm{O}$, and $\mathrm{C}-\mathrm{H}$, respectively (Inyang et al., 2010; Yao et al., 2011). After Cd(II) adsorption, XRD analysis of biochars was conducted and shown in Fig. 5, and it indicated that the crystal precipitations on fresh biochars (BC and 
MBC) were mainly existed in the forms of $\mathrm{CaCO}_{3}, \mathrm{CdCO}_{3}$ and $\mathrm{CaC}_{2} \mathrm{O}_{4}$; however, after aging without soil or co-aging with soils, due to the consumption of alkaline mineral precipitation during the aging process, $\mathrm{CaCO}_{3}$ and $\mathrm{CdCO}_{3}$ disappeared while $\mathrm{SiO}_{2}$ appeared, which might have a greater impact on the contribution of precipitation, and in turn led to a significant decrease in adsorption capacity of biochar.

\subsection{Adsorption behaviors of aged biochars}

The adsorption isotherms of $\mathrm{Cd}(\mathrm{II})$ on aged biochars $(\mathrm{PBC}, \mathrm{PMBC}, \mathrm{ABC}, \mathrm{AMBC}, \mathrm{BBC}, \mathrm{BMBC}, \mathrm{CBC}$ and CMBC) are shown in Fig. 6. For all aged biochars, the fitting results of Freundlich isotherm model basically had larger $R^{2}$ values (ranging from 0.941 to 0.992 ), which were quite different from the fitting results of fresh biochars, indicating that aging processes (aging without soil or co-aging with soils) changed the adsorption of biochars into heterogeneous multilayer adsorption (Tran et al., 2017). Deng et al. (2020) also found that the adsorption of fresh biochars for $\mathrm{Cd}$ (II) and $\mathrm{Ni}$ (II) was better fitted by the Langmuir model, while that of aged biochar was better fitted by the Freundlich model. Tan et al. (2020) showed that the adsorption data of fresh and aged biochars for $\mathrm{Pb}$ (II) were more suitable for Langmuir model and Freundlich model, respectively.

Since part of adsorption data could not be well fitted by Langmuir model, in this study, the adsorption capacities of biochars at $\mathrm{Q}_{\mathrm{e}}=200 \mathrm{mg} \cdot \mathrm{L}^{-1}$ were used as the maximum adsorption capacities. For original biochars, the order of adsorption capacities was CBC $\left(63.50 \mathrm{mg} \cdot \mathrm{g}^{-1}\right)>\mathrm{BC}\left(54.80 \mathrm{mg} \cdot \mathrm{g}^{-1}\right)>$ PBC $(50.08$ $\left.\mathrm{mg} \cdot \mathrm{g}^{-1}\right)>\mathrm{BBC}\left(36.33 \mathrm{mg} \cdot \mathrm{g}^{-1}\right)>\mathrm{ABC}\left(31.17 \mathrm{mg} \cdot \mathrm{g}^{-1}\right)$; and for modified biochars, the order of adsorption capacities was MBC $\left(126.91 \mathrm{mg} \cdot \mathrm{g}^{-1}\right)>$ PMBC $\left(105.83 \mathrm{mg} \cdot \mathrm{g}^{-1}\right)>\mathrm{CMBC}\left(86.25 \mathrm{mg} \cdot \mathrm{g}^{-1}\right)>$ AMBC $(83.00$ $\left.\mathrm{mg} \cdot \mathrm{g}^{-1}\right)>\mathrm{BMBC}\left(82.33 \mathrm{mg} \cdot \mathrm{g}^{-1}\right)$. The adsorption capacity percentages of aged biochars divided by fresh biochars were calculated, for original biochars, the percentages were $91.4 \%$ (PBC), 56.9\% (ABC), 66.3\% (BBC), 115.9\% (CBC); and those of modified biochars were 83.4\% (PMBC), 65.4\% (AMBC), 64.9\% (BMBC), $68.0 \%$ (CMBC). Except for the original biochar co-aged with alkaline soil increased the adsorption capacity, the other aging treatments all decreased the adsorption capacities of biochars. Moreover, for biochars co-aged with soils, the adsorption capacities basically decreased with the increase of soil acidity.

It could be seen from Table 1 that the order of modified biochar pH was MBC (9.60) > PMBC (7.92) > CMBC (7.56) > BMBC (6.10) > AMBC (6.00), which was basically same as the order of adsorption capacities, indicating that the $\mathrm{pH}$ of soil had a crucial influence on the adsorption capacity of co-aged biochar. It was noteworthy that the adsorption result of aged biochar without soil was far from that of coaged biochars; therefore, the single biochar aging cannot be used to predict the adsorption behaviors of biochar after aging in soils.

\subsection{Quantitative adsorption mechanisms of biochars for Cd(II)}

\subsubsection{Cation exchange with $\mathrm{K}(\mathrm{I}), \mathrm{Ca}(\mathrm{II}), \mathrm{Na}(\mathrm{I})$, and $\mathrm{Mg}(\mathrm{II})$}


$\mathrm{Cd}(\mathrm{II})$ in solution can be adsorbed on biochars by cation exchange with $\mathrm{K}(\mathrm{I}), \mathrm{Ca}(\mathrm{II}), \mathrm{Na}(\mathrm{I})$ and $\mathrm{Mg}(\mathrm{II})$ ( $\mathrm{Lu}$ et al., 2012). Monovalent cations $(\mathrm{K}(\mathrm{I})$ and $\mathrm{Na}(\mathrm{I})$ ) and divalent cations ( $\mathrm{Ca}(\mathrm{II})$ and $\mathrm{Mg}(\mathrm{II})$ ) present in different forms on biochars; monovalent cations are retained by electrostatic outer-sphere interactions, while divalent cations are retained by precipitation and inner-sphere complexation with oxygen-containing surface functional groups (Cui et al., 2016; Lu et al., 2012). All these four ions can directly exchange with $\mathrm{Cd}(\mathrm{II})$, and Zhang et al. (2015) indicated that hydroxylated $\mathrm{SiO}_{2}$ and $\mathrm{Al}_{2} \mathrm{O}_{3}$ on the biochar surface provided sites for cation exchange.

To quantify this mechanism, the net releases of these four ions were calculated, where every two $\mathrm{K}(\mathrm{I})$ or $\mathrm{Na}(\mathrm{I})$ exchanged one $\mathrm{Cd}(\mathrm{II})$, and $\mathrm{Ca}(\mathrm{II})$ or $\mathrm{Mg}(\mathrm{II})$ exchanged with $\mathrm{Cd}(\mathrm{II})$ in equal amount, and the results were shown in Table S1. The adsorption capacities of $B C, M B C, P B C, P M B C, A B C, A M B C, B B C, B M B C$, $\mathrm{CBC}$ and $\mathrm{CMBC}$ due to the cation exchange with $\mathrm{K}(\mathrm{I}), \mathrm{Ca}(\mathrm{II}), \mathrm{Na}(\mathrm{I})$ and $\mathrm{Mg}(\mathrm{II})\left(\mathrm{Q}_{\mathrm{cic}}\right)$ were $6.05,6.48,9.22$, $4.56,0.64,3.63,2.22,4.94,0$ and $1.82 \mathrm{mg} \cdot \mathrm{g}^{-1}$, respectively. The $\mathrm{Q}_{\mathrm{cic}}$ of $\mathrm{MBC}$ was close to that of $\mathrm{BC}$, indicating that the premodification of $\mathrm{KMnO}_{4}$ had almost no effect on this mechanism. Except for aged original biochar without soil, after aging, the contribution of cation exchange with $\mathrm{K}(\mathrm{I}), \mathrm{Ca}(\mathrm{II}), \mathrm{Na}(\mathrm{I})$ and $\mathrm{Mg}(\mathrm{II})$ to the adsorption capacities of biochars all decreased, possibly caused by releasing or exchanging with other ions in soil during the aging process.

\subsubsection{Cation exchange with $\mathrm{Mn}(\mathrm{II})$}

The EDS analysis showed that $\mathrm{Mn}(\mathrm{II})$ appeared on the surface of $\mathrm{MBC}$ by the redox reaction between $\mathrm{KMnO}_{4}$ and straw powder. The adsorption capacities due to the cation exchange with $\mathrm{Mn}$ (II) on $\mathrm{MBC}$, PMBC, AMBC, BMBC and CMBC were 11.39, 13.02, 2.95, 1.93 and $3.78 \mathrm{mg} \cdot \mathrm{g}^{-1}$, respectively, which indicated that the contributions of cation exchange with $\mathrm{Mn}$ (II) were all significantly decreased after coaging with soils, however, the contribution of this mechanism after aging without soil slightly increased. Moreover, it is noting that the decrease in contribution of this mechanism was obviously larger than that of cation exchange with $\mathrm{K}(\mathrm{I}), \mathrm{Ca}(\mathrm{II}), \mathrm{Na}(\mathrm{I})$ and $\mathrm{Mg}(\mathrm{II})$ after co-aging with soils, indicating that the newly emerged $\mathrm{Mn}(\mathrm{II})$ due to the modification was more easily exchanged with other ions or released in soil during the aging process.

\subsubsection{Precipitation and adsorption with minerals}

Minerals on biochars can co-precipitate with Cd(II) to achieve adsorption (Cui et al., 2016), in this study, this mechanism was redefined, which included not only the precipitation, but also the adsorption with minerals due to the existence of $\mathrm{MnO}_{\mathrm{x}}$ on biochar after the modification with $\mathrm{KMnO}_{4}$. After premodification with $\mathrm{KMnO}_{4}$, the carbonate content of $\mathrm{MBC}$ significantly increased (Table 1), and in turn improved the adsorption capacity caused by precipitation; and both the XRD (Fig. 5) and XPS (Fig. 3a, b) analysis showed that crystalline $\mathrm{Cd}(\mathrm{II})$ mainly existed in the form of $\mathrm{CdCO}_{3}$. The adsorption capacities of $B C, M B C, P B C, P M B C, A B C, A M B C, B B C, B M B C, C B C$ and $C M B C$ due to the precipitation and adsorption with minerals $\left(Q_{c p}\right)$ were $37.85,64.85,32.16,45.19,21.28,25.41,15.98,31.37,32.18$ and $49.20 \mathrm{mg} \cdot \mathrm{g}^{-1}$, respectively. The XRD analysis (Fig. 5) revealed that almost all the mineral components on biochar 
became $\mathrm{SiO}_{2}$ with the disappear of $\mathrm{CaCO}_{3}$ and $\mathrm{CdCO}_{3}$ after aging, and occasionally a small amount of $\mathrm{CaC}_{2} \mathrm{O}_{4}$ appeared, which resulted in the obvious decrease in the contribution of $\mathrm{Q}_{\mathrm{cp}}$.

\subsubsection{Complexation with acidic surface functional groups}

Many previous researchers demonstrated that complexation with acidic surface functional groups was one of the important adsorption mechanisms of biochars for $\mathrm{Cd}(\mathrm{II})$, and the contribution of this mechanism to adsorption capacity was calculated by the $\mathrm{pH}$ differences of $\mathrm{Cd}$ (II) solution before and after reaction with demineralized biochar (Cui et al., 2016; Wang et al., 2015b; Xu et al., 2013); moreover, the complexation of $\mathrm{Cd}(\mathrm{II})$ with acidic surface functional groups was accompanied by the release of $\mathrm{H}^{+}$, indicating that the lower the $\mathrm{pH}$ value of $\mathrm{Cd}(\mathrm{II})$ solution after reaction, the greater the contribution to adsorption capacity by this mechanism. However, as shown in Fig. 7a, the contributions of complexation with acidic surface functional groups to adsorption capacities of rice straw biochars were the smallest among all five mechanisms.

\subsubsection{Other potential mechanisms}

In addition to the above four adsorption mechanisms, there are some mechanisms that cannot be distinguished, including electrostatic attraction, physical adsorption and cation- $\pi$ interactions (Deng et al., 2017; Mahdi et al., 2018). Electrostatic attraction depends on the biochar point of zero charge $\left(\mathrm{pH}_{\mathrm{pzc}}\right)$ and the $\mathrm{pH}$ of solution, and when the $\mathrm{pH}$ of solution is greater than $\mathrm{pH}_{\mathrm{pzc}}$, the surface of the biochar is negatively charged, leading to the Cd(II) adsorption by biochar (Han et al., 2013a). Many previous studies (Jiang et al., 2016; Tran et al., 2017) indicated that physical adsorption was mainly related to the microporous structure and specific surface area of biochar; and aromatic carbon on the biochar surface produced electron-rich $\pi$-systems and interacted with $\mathrm{Cd}(\mathrm{II})$. The adsorption capacities of $B C, M B C, P B C$, PMBC, $A B C, A M B C, B B C, B M B C, C B C$ and $C M B C$ due to this mechanism were 9.88, 15.10, 8.33, 5.39, 2.95, $11.40,6.81,3.80,8.33$ and $3.19 \mathrm{mg} \cdot \mathrm{g}^{-1}$, respectively, which showed that aging without soil and co-aging with soils decreased the contributions of other potential mechanisms to the adsorption capacity of biochars.

\subsubsection{Overall analysis of five mechanisms}

It could be seen from Fig. 7a that the increase in the adsorption capacity of MBC compared with BC was mainly caused by precipitation and adsorption with minerals and cation exchange with $\mathrm{Mn}(\mathrm{II})$. Fig. $7 \mathrm{~b}$ showed that precipitation and adsorption with minerals accounted for $70.36 \%, 66.29 \%, 64.68 \%, 66.28 \%$, $85.55 \%, 58.55 \%, 63.92 \%, 74.63 \%, 79.40 \%$ and $84.83 \%$ of the total adsorption capacities of BC, MBC, PBC, $\mathrm{PMBC}, \mathrm{ABC}, \mathrm{AMBC}, \mathrm{BBC}, \mathrm{BMBC}, \mathrm{CBC}$ and $\mathrm{CMBC}$ respectively, indicating that even if the original and modified rice straw biochars underwent different aging progresses (aging without soil and co-aging with different types of soil), the main adsorption mechanism of biochars for $\mathrm{Cd}(\mathrm{II})$ was still the precipitation and adsorption with minerals.

The contributions of all five mechanisms to the adsorption capacities of aged biochars for Cd(II) basically showed a downward trend. For original biochar, after aging without soil, co-aging with acidic 
and neutral soils, the contributions of the precipitation and adsorption with minerals decreased the most, namely $5.69,16.58$ and $21.87 \mathrm{mg} \cdot \mathrm{g}^{-1}$, while after co-aging with alkaline soil, the contribution of cation exchange with $\mathrm{K}(\mathrm{I}), \mathrm{Ca}(\mathrm{II}), \mathrm{Na}(\mathrm{I})$ and $\mathrm{Mg}(\mathrm{II})$ decreased the most $\left(6.05 \mathrm{mg} \cdot \mathrm{g}^{-1}\right)$. In terms of modified biochar, all aging processes decreased the contributions of precipitation and adsorption with minerals the most, namely $19.66,39.43,33.48,15.65 \mathrm{mg} \cdot \mathrm{g}^{-1}$ for aging without soil, co-aging with acidic, neutral and alkaline soils, respectively. Deng et al. (2020) conducted a one-year constant temperature and humidity aging on single biochar, and the adsorption experimental results of $\mathrm{Cd}(\mathrm{II})$ and $\mathrm{Ni}(\mathrm{II})$ also indicated that aging significantly reduced the contributions of precipitation and cation exchange to the adsorption capacities of biochar. In general, the adsorption capacity of MBC decreased more than that of BC after aging (aging without soil or co-aging with soils); moreover, co-aging with acidic and neutral soils had a greater negative impact on the contributions of all mechanisms than aging without soil and co-aging with alkaline soil.

\section{Conclusion}

The premodification of $\mathrm{KMnO}_{4}$ significantly improved $\mathrm{Cd}(\mathrm{II})$ adsorption capacity and adaptability of rice straw biochar, which benefited from the increase of carbonate content, specific surface area and the emergence of $\mathrm{Mn}(\mathrm{II})$ and $\mathrm{MnO}_{\mathrm{x}}$. Even after co-aging with soils, $\mathrm{Cd}(\mathrm{II})$ adsorption capacities of modified biochar were always larger than those of original biochar. Moreover, $\mathrm{Cd}$ (II) adsorption capacities were basically in the order of aged biochar without soil > biochar co-aged with alkaline soil > biochar co-aged with neutral soil > biochar co-aged with acid soil. The contribution of cation exchange in premodified biochar was always larger than that in original biochar due to the emergence of $\mathrm{Mn}$ (II) by modification. Whether aging or not, the dominant adsorption mechanism of original and premodified biochars for $\mathrm{Cd}(\mathrm{II})$ was all the precipitation and adsorption with minerals. In this study, we highlighted that biochar remediation for $\mathrm{Cd}$ should be evaluated by co-aging with soil instead of aging without soil.

\section{Declarations}

\section{Data availability}

All data gathered or analyzed during this study are included in this paper.

\section{Funding}

This work was supported by the National Natural Science Foundation of China (No. 52179040).

\section{Author information}

\section{Affiliations}

State Key Laboratory of Water Resources and Hydropower Engineering Sciences, Wuhan University, Wuhan 430072, China. 
Zhuowen Meng \& Shuang Huang \& Zhongbing Lin.

\section{Contributions}

Zhuowen Meng: Data curation, Formal analysis, Investigation, Writing-original draft. Shuang Huang: Conceptualization, Writing-review \& editing, Resources.

Zhongbing Lin: Writing-review \& editing.

\section{Corresponding author}

Correspondence to Shuang Huang.

\section{Ethics declarations}

\section{Consent for publication}

The authors agree to participate and publish.

\section{Competing interests}

The authors declare no competing interests.

\section{References}

1. Ahmad Z, Gao B, Mosa A, Yu H, Yin X, Bashir A, Ghoveisi H, Wang S 2018. Removal of Cu(II), Cd(II) and $\mathrm{Pb}$ (II) ions from aqueous solutions by biochars derived from potassium-rich biomass. Journal of Cleaner Production180,437-449. doi: 10.1016/j.jclepro.2018.01.133

2. Biesinger MC, Payne BP, Grosvenor AP, Lau LWM, Gerson AR, Smart RSC 2011. Resolving surface chemical states in XPS analysis of first row transition metals, oxides and hydroxides: $\mathrm{Cr}, \mathrm{Mn}, \mathrm{Fe}, \mathrm{Co}$ and Ni.Applied Surface Science, 257(7),2717-2730. doi: 10.1016/j.apsusc.2010.10.051

3. Bogusz A, Oleszczuk P, Dobrowolski R 2015. Application of laboratory prepared and commercially available biochars to adsorption of cadmium, copper and zinc ions from water.Bioresour Technol, 196,540-9. doi: 10.1016/j.biortech.2015.08.006

4. Cai T, Liu X, Zhang J, Tie B, Lei M, Wei X, Peng O, Du H 2021. Silicate-modified oiltea camellia shellderived biochar: A novel and cost-effective sorbent for cadmium removal.Journal of Cleaner Production281,125390.doi: 10.1016/j.jclepro.2020.125390

5. Chang R, Sohi SP, Jing F, Liu Y, Chen J 2019. A comparative study on biochar properties and Cd adsorption behavior under effects of ageing processes of leaching, acidification and oxidation.Environ Pollut254,113123.doi: 10.1016/j.envpol.2019.113123

6. Chen HY, Yao J, Zhou Y, Chen HL, Wang F, Gai N, Zhuang RS, Ceccanti B, Maskow T, Zaray G 2008. Investigation of the toxic effect of cadmium on Candida humicola and Bacillus subtilis using a microcalorimetric method.J Hazard Mater, 159(2-3),465-70. doi: 10.1016/j.jhazmat.2008.02.040 
7. Cui X, Fang S, Yao Y, Li T, Ni Q, Yang X, He Z 2016. Potential mechanisms of cadmium removal from aqueous solution by Canna indica derived biochar.Sci Total Environ, 562,517-525. doi: 10.1016/j.scitotenv.2016.03.248

8. Deng J, Liu Y, Liu S, Zeng G, Tan X, Huang B, Tang X, Wang S, Hua Q, Yan Z 2017. Competitive adsorption of $\mathrm{Pb}(\mathrm{II}), \mathrm{Cd}(\mathrm{II})$ and $\mathrm{Cu}(\mathrm{II})$ onto chitosan-pyromellitic dianhydride modified biochar.J Colloid Interface Sci, 506,355-364. doi: 10.1016/j.jcis.2017.07.069

9. Deng Y, Huang S, Dong C, Meng Z, Wang X 2020. Competitive adsorption behaviour and mechanisms of cadmium, nickel and ammonium from aqueous solution by fresh and ageing rice straw biochars.Bioresour Technol303,122853.doi: 10.1016/j.biortech.2020.122853

10. Deng Y, Huang S, Laird DA, Wang X, Meng Z 2019. Adsorption behaviour and mechanisms of cadmium and nickel on rice straw biochars in single-and binary-metal systems.Chemosphere, 218,308-318. doi: 10.1016/j.chemosphere.2018.11.081

11. Deng Y, Huang S, Laird DA, Wang X, Dong C 2018. Quantitative mechanisms of cadmium adsorption on rice straw- and swine manure-derived biochars. Environ Sci Pollut Res Int25,32418-32432.doi: 10.1007/s11356-018-2991-1

12. Dutta B, Raghavan VGS, Orsat V, Ngadi M 2015. Surface characterisation and classification of microwave pyrolysed maple wood biochar.Biosystems Engineering, 131,49-64. doi: 10.1016/j.biosystemseng.2015.01.002

13. Fan Z, Zhang Q, Li M, Niu D, Sang W, Verpoort F 2018. Investigating the sorption behavior of cadmium from aqueous solution by potassium permanganate-modified biochar: quantify mechanism and evaluate the modification method. Environ Sci Pollut Res Int, 25(9),8330-8339. doi: 10.1007/s11356-017-1145-1

14. Fan Z, Zhang Q, Li M, Sang W, Qiu Y, Wei X, Hao H 2020. Removal behavior and mechanisms of Cd(II) by a novel MnS loaded functional biochar: Influence of oxygenation. Journal of Cleaner Production256,120672.doi: 10.1016/j.jclepro.2020.120672

15. Hadjittofi L, Prodromou M, Pashalidis I 2014. Activated biochar derived from cactus fibrespreparation, characterization and application on $\mathrm{Cu}(\mathrm{II})$ removal from aqueous solutions.Bioresour Technol, 159,460-4. doi: 10.1016/j.biortech.2014.03.073

16. Han X, Liang CF, Li TQ, Wang K, Huang HG, Yang XE 2013a. Simultaneous removal of cadmium and sulfamethoxazole from aqueous solution by rice straw biochar.J Zhejiang Univ Sci B, 14(7),640-9. doi: $10.1631 /$ jzus.B1200353

17. Han Y, Boateng AA, Qi PX, Lima IM, Chang J 2013b. Heavy metal and phenol adsorptive properties of biochars from pyrolyzed switchgrass and woody biomass in correlation with surface properties.J Environ Manage, 118,196-204. doi: 10.1016/j.jenvman.2013.01.001

18. Inyang M, Gao B, Pullammanappallil P, Ding W, Zimmerman AR 2010. Biochar from anaerobically digested sugarcane bagasse.Bioresour Technol, 101(22),8868-72. doi:

10.1016/j.biortech.2010.06.088 
19. Inyang M, Gao B, Yao Y, Xue Y, Zimmerman AR, Pullammanappallil P, Cao X 2012. Removal of heavy metals from aqueous solution by biochars derived from anaerobically digested biomass.Bioresour Technol, 110,50-6. doi: 10.1016/j.biortech.2012.01.072

20. Jiang S, Huang L, Nguyen TA, Ok YS, Rudolph V, Yang H, Zhang D 2016. Copper and zinc adsorption by softwood and hardwood biochars under elevated sulphate-induced salinity and acidic $\mathrm{pH}$ conditions. Chemosphere, 142,64-71. doi: 10.1016/j.chemosphere.2015.06.079

21. Li B, Yang L, Wang CQ, Zhang QP, Liu QC, Li YD, Xiao R 2017. Adsorption of Cd(II) from aqueous solutions by rape straw biochar derived from different modification processes. Chemosphere, 175,332-340. doi: 10.1016/j.chemosphere.2017.02.061

22. Li Z, Katsumi T, Imaizumi S, Tang X, Inui T 2010. Cd(II) adsorption on various adsorbents obtained from charred biomaterials. J Hazard Mater, 183(1-3),410-20. doi: 10.1016/j.jhazmat.2010.07.040

23. Liang J, Li X, Yu Z, Zeng G, Luo Y, Jiang L, Yang Z, Qian Y, Wu H 2017. Amorphous MnO2 Modified Biochar Derived from Aerobically Composted Swine Manure for Adsorption of Pb(II) and Cd(II).ACS Sustainable Chemistry \& Engineering, 5(6),5049-5058. doi: 10.1021/acssuschemeng.7b00434

24. Liu L, Fan S 2018. Removal of cadmium in aqueous solution using wheat straw biochar: effect of minerals and mechanism. Environ Sci Pollut Res Int, 25(9),8688-8700. doi: 10.1007/s11356-0171189-2

25. Liu W, Zhou Q, An J, Sun Y, Liu R 2010. Variations in cadmium accumulation among Chinese cabbage cultivars and screening for Cd-safe cultivars.J Hazard Mater, 173(1-3), 737-43.doi: 10.1016/j.jhazmat.2009.08.147

26. Lu H, Zhang W, Yang Y, Huang X, Wang S, Qiu R 2012. Relative distribution of Pb2+ sorption mechanisms by sludge-derived biochar. Water Res, 46(3),854-62. doi: 10.1016/j.watres.2011.11.058

27. Lyu H, Gao B, He F, Zimmerman AR, Ding C, Huang H, Tang J 2018. Effects of ball milling on the physicochemical and sorptive properties of biochar: Experimental observations and governing mechanisms. Environ Pollut, 233,54-63. doi: 10.1016/j.envpol.2017.10.037

28. Mahdi Z, Yu QJ, El Hanandeh A 2018. Investigation of the kinetics and mechanisms of nickel and copper ions adsorption from aqueous solutions by date seed derived biochar. Journal of Environmental Chemical Engineering, 6(1),1171-1181. doi: 10.1016/j.jece.2018.01.021

29. Meng J, Wang L, Liu X, Wu J, Brookes PC, Xu J 2013. Physicochemical properties of biochar produced from aerobically composted swine manure and its potential use as an environmental amendment.Bioresour Technol, 142,641-6. doi: 10.1016/j.biortech.2013.05.086

30. Meng Z, Huang S, Xu T, Deng Y, Lin Z, Wang X 2020. Transport and transformation of Cd between biochar and soil under combined dry-wet and freeze-thaw aging. Environ Pollut263,114449.doi: 10.1016/j.envpol.2020.114449

31. Qian L, Zhang W, Yan J, Han L, Gao W, Liu R, Chen M 2016. Effective removal of heavy metal by biochar colloids under different pyrolysis temperatures.Bioresour Technol, 206,217-224. doi: 10.1016/j.biortech.2016.01.065 
32. Quan G, Fan Q, Cui L, Zimmerman AR, Wang H, Zhu Z, Gao B, Wu L, Yan J (2020) Simulated photocatalytic aging of biochar in soil ecosystem: Insight into organic carbon release, surface physicochemical properties and cadmium sorption. 183:109241.

10.1016/j.envres.2020.109241.Environ Resdoi:

33. Rajapaksha AU, Vithanage M, Ahmad M, Seo DC, Cho JS, Lee SE, Lee SS, Ok YS 2015. Enhanced sulfamethazine removal by steam-activated invasive plant-derived biochar.J Hazard Mater, 290,4350. doi: 10.1016/j.jhazmat.2015.02.046

34. Rizwan M, Ali S, Adrees M, Rizvi H, Zia-Ur-Rehman M, Hannan F, Qayyum MF, Hafeez F, Ok YS 2016. Cadmium stress in rice: toxic effects, tolerance mechanisms, and management: a critical review. Environ Sci Pollut Res Int, 23(18), 17859-79. doi: 10.1007/s11356-016-6436-4

35. Song Z, Lian F, Yu Z, Zhu L, Xing B, Qiu W 2014. Synthesis and characterization of a novel MnOxloaded biochar and its adsorption properties for $\mathrm{Cu} 2+$ in aqueous solution.Chemical Engineering Journal, 242,36-42. doi: 10.1016/j.cej.2013.12.061

36. Sun L, Wan S, Luo W 2013. Biochars prepared from anaerobic digestion residue, palm bark, and eucalyptus for adsorption of cationic methylene blue dye: characterization, equilibrium, and kinetic studies.Bioresour Technol, 140,406-13. doi: 10.1016/j.biortech.2013.04.116

37. Tan L, Ma Z, Yang K, Cui Q, Wang K, Wang T, Wu GL, Zheng J (2020) Effect of three artificial aging techniques on physicochemical properties and $\mathrm{Pb}$ adsorption capacities of different biochars. 699:134223. 10.1016/j.scitotenv.2019.134223.Sci Total Environdoi:

38. Trakal L, Bingol D, Pohorely M, Hruska M, Komarek M 2014. Geochemical and spectroscopic investigations of $\mathrm{Cd}$ and $\mathrm{Pb}$ sorption mechanisms on contrasting biochars: engineering implications.Bioresour Technol, 171,442-51. doi: 10.1016/j.biortech.2014.08.108

39. Tran HN, You SJ, Hosseini-Bandegharaei A, Chao HP 2017. Mistakes and inconsistencies regarding adsorption of contaminants from aqueous solutions: A critical review. Water Res, 120,88-116. doi: 10.1016/j.watres.2017.04.014

40. Wang H, Gao B, Wang S, Fang J, Xue Y, Yang K 2015a. Removal of Pb(II), Cu(II), and Cd(II) from aqueous solutions by biochar derived from KMnO4 treated hickory wood.Bioresour Technol, 197,35662. doi: $10.1016 /$ j.biortech.2015.08.132

41. Wang L, O'Connor D, Rinklebe J, Ok YS, Tsang DCW, Shen Z, Hou D 2020. Biochar Aging: Mechanisms, Physicochemical Changes, Assessment, And Implications for Field Applications.Environ Sci Technol54,14797-14814.doi: 10.1021/acs.est.0c04033

42. Wang S, Zhou Y, Gao B, Wang X, Yin X, Feng K, Wang J 2017. The sorptive and reductive capacities of biochar supported nanoscaled zero-valent iron ( $\mathrm{ZZVI}$ ) in relation to its crystallite size.Chemosphere, 186,495-500. doi: 10.1016/j.chemosphere.2017.08.014

43. Wang Z, Liu G, Zheng H, Li F, Ngo HH, Guo W, Liu C, Chen L, Xing B 2015b. Investigating the mechanisms of biochar's removal of lead from solution.Bioresour Technol, 177,308-17. doi: 10.1016/j.biortech.2014.11.077 
44. Xiao Z, Zhang L, Wu L, Chen D 2019. Adsorptive removal of Cu(II) from aqueous solutions using a novel macroporous bead adsorbent based on poly(vinyl alcohol)/sodium alginate/KMnO4 modified biochar. Journal of the Taiwan Institute of Chemical Engineers, 102,110-117. doi: 10.1016/j.jtice.2019.05.010

45. Xu X, Cao X, Zhao L 2013. Comparison of rice husk-and dairy manure-derived biochars for simultaneously removing heavy metals from aqueous solutions: role of mineral components in biochars. Chemosphere, 92(8),955-61. doi: 10.1016/j.chemosphere.2013.03.009

46. Xu Z, Xu X, Tsang DCW, Cao X 2018. Contrasting impacts of pre-and post-application aging 605 of biochar on the immobilization of Cd in contaminated soils. Environ Pollut, 242(Pt B),60613621370.doi: 10.1016/j.envpol.2018.08.012

47. Yao Y, Gao B, Inyang M, Zimmerman AR, Cao X, Pullammanappallil P, Yang L 2011. Biochar derived from anaerobically digested sugar beet tailings: characterization and phosphate removal potential.Bioresour Technol, 102(10),6273-8. doi: 10.1016/j.biortech.2011.03.006

48. Yin G, Bi L, Song X, Luo H, Ji P, Lin Q, Liu Q, Tang G 2019. Adsorption of Cd(II) from aqueous solution by Pennisetum sp. straw biochars derived from different modification methods. Environ Sci Pollut Res Int, 26(7),7024-7032. doi: 10.1007/s11356-019-04158-6

49. Zhang F, Wang X, Yin D, Peng B, Tan C, Liu Y, Tan X, Wu S 2015. Efficiency and mechanisms of Cd removal from aqueous solution by biochar derived from water hyacinth (Eichornia crassipes). $J$ Environ Manage, 153,68-73. doi: 10.1016/j.jenvman.2015.01.043

\section{Figures}




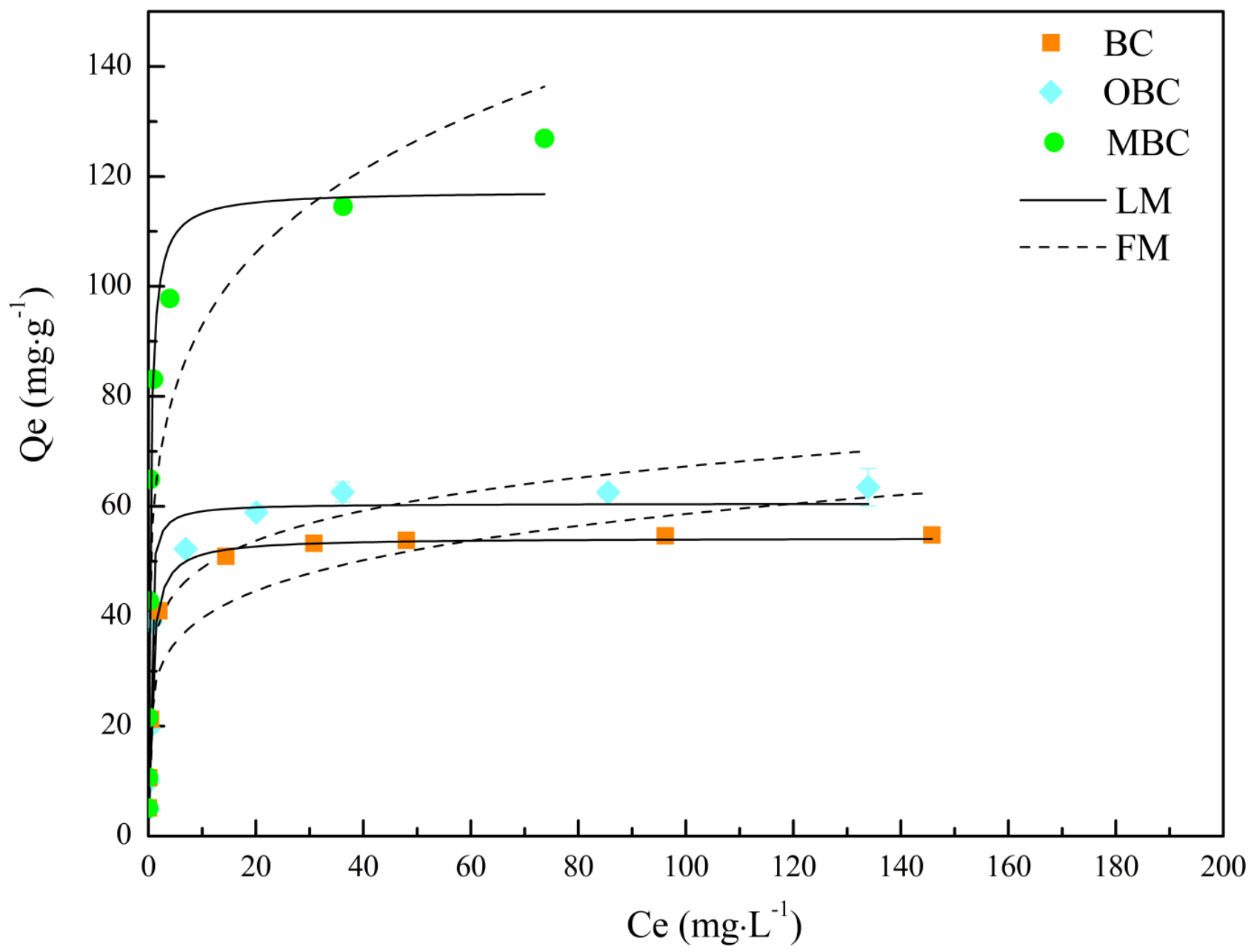

Figure 1

Adsorption isotherm data fitted by the Langmuir and Freundlich models for $\mathrm{Cd}(\mathrm{II})$ adsorption onto $\mathrm{BC}$, $\mathrm{MBC}$ and $\mathrm{OBC}$. 

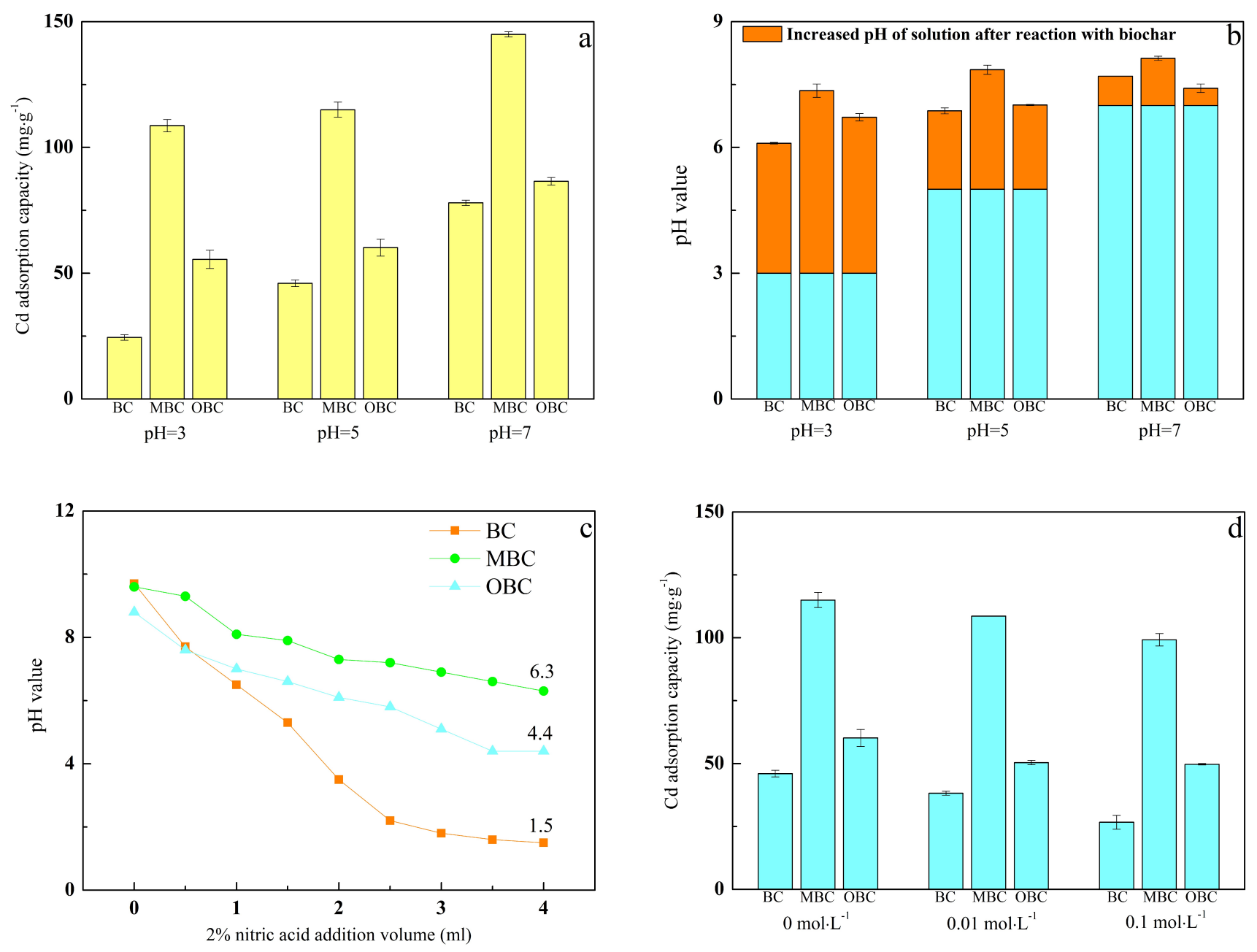

Figure 2

Adsorption capacities of biochars (BC, MBC and $\mathrm{OBC}$ ) in $\mathrm{Cd}(\mathrm{II})$ solution with different $\mathrm{pH}$ values (a) and ionic strengths $(\mathrm{d})$. The solution $\mathrm{pH}$ values after reaction and the results of the acid buffer experiment are shown in $\mathrm{b}$ and $\mathrm{c}$.

\section{Figure 3}

XPS scans of MBC and OBC after Cd(II) adsorption: wide scan (a), Cd3d (b), Mn2p (c), Mn3s (d).

\section{Figure 4}

FTIR spectra of biochars ( $B C, M B C, P B C, P M B C, A B C, A M B C, B B C, B M B C, C B C$ and $C M B C)$, and the specific information has been identified in the figure. 
Figure 5

XRD image of biochars after $C d(I I)$ adsorption $(B C, M B C, P B C, P M B C, A B C, A M B C, B B C, B M B C, C B C$ and $\mathrm{CMBC})$, and the specific information has been identified in the figure.

150 $\cdots$
$150 \lessdot$

\section{Figure 6}

Adsorption isotherm data fitted by the Langmuir and Freundlich models for $\mathrm{Cd}$ (II) adsorption onto PBC, PMBC (a), ABC, AMBC (b), BBC, BMBC (c), CBC and CMBC (d). 


\section{Figure 7}

The estimated contributions to $C d(I I)$ adsorption on the biochars $(B C, M B C, P B C, P M B C, A B C, A M B C, B B C$, $B M B C, C B C$ and $C M B C$ ) attributed to cation exchange with $\mathrm{K}(\mathrm{I}), \mathrm{Ca}(\mathrm{II}), \mathrm{Na}(\mathrm{I})$, and $\mathrm{Mg}(\mathrm{II})$, cation exchange with $\mathrm{Mn}(\mathrm{II})$, precipitation and adsorption with minerals, complexation with acid surface functional groups and other potential mechanism.

\section{Supplementary Files}

This is a list of supplementary files associated with this preprint. Click to download.

- Supplementarymaterial.docx 